\title{
Criminalization of Voluntary Incest Among Adults in Comparative Perspective
}

\author{
Tamta Sajaia, (PhD student) \\ Grigol Robakidze University, Georgia
}

Doi:10.19044/esj.2018.v14n17p269 URL:http://dx.doi.org/10.19044/esj.2018.v14n17p269

\begin{abstract}
In the present article - "Criminalization of Voluntary Incest Among Adults in Comparative Perspective" - the author fully shares the opinion that prohibition of incest is a major step taken by human beings from their original natural state towards civilization.

Intimate relations between blood relatives can destroy the family structure and the whole society. It can ruin the moral principles of the democratic state and serve as a basis for producing genetically abnormal offspring. Consequently, the negative attitude to the "incestuous relations" is universal and well known to the civilization; although, the interpretation of such relations and the social and legal forms of making impact on it are different, thus, the complexity of legislative approaches, revealing the importance of the issue.

The definition of incest has been worked out on the basis of: a) formulation of public attitudes toward incest and revealing the main tendencies of the development of the legislation in the historical context; b) comparison of the national legislation with the legislative base of other states worldwide and their legal systems; c) analysis of the practice of the European Court of Human Rights and the scientific research works on related topics. In order to initiate criminalization of voluntary incest among adults, the definitions tailored to the Georgian legislation have been elaborated.
\end{abstract}

Keywords: Family, Crime, Incest, Incestuous relations

\section{Introduction}

As a result of the development of civilization, every aspect of human life underwent formation, but public opinion towards such a phenomenon as family, remained unchanged.

The social category of family has always been characterized by special values and considered as the main part of public life. For these reasons, the actions against family unity and dignity were subjects to condemnation. 
It is noteworthy that sexual intercourse has always been the main aspect of family relations; though, the rules and norms of behavior established by the society largely influenced these relationships. A clear example of this is a historical taboo on sexual intercourse between close relatives, the so-called "incest".

Claude Levi-Strauss considered that "Prohibition of Incest" is a major step taken by human beings from their original natural state towards civilization (Levi-Strauss, 1967). From endogenous relationships within the scope of which sexual intercourse and marriages were permitted among the blood-related people, the civilization has gone through a long and complex socio-cultural way before the formation of exogamy.

Ancient Egypt, which was the country of model legislation and order, did not distinguish itself by the ideal morality of family values - in the aristocracy and royal circles, marriage between brothers and sisters was common; Pharaohs were married to their daughters (Ramses II) and their fathers' widows (Nadareishvili, 1996).

Greek mythology gives us the details of intimate life proving that incest was common and not prohibited (the myth about Oedipus).

The precedents of aristocratic incestuous relations are found in the history of Old Rome. Namely, according to Suetonius, Gaius Julius Caesar, known as Caligula, committed sexual intercourse with all his three young sisters (Suetonius, Book IV); while other Roman citizens were charged of marriage between the relatives of ascending and descending lines (Suetonius, Book I). In Mesopotamia, incest was strictly condemned; in particular, according to Hammurabi's law, those who were in intimate relationship with their mothers or sons were burned in the fire (Dolidze, 1960).

According to Chinese Criminal Law, incest was considered as the $10^{\text {th }}$ evil, which, on its turn, was equal to 'birds' and animals' behaviors" (Nadareishvili, 1986).

In the Christian world, the Bible is considered as one of the oldest documents that announces incest as deviant. According to the Bible, the first incest on earth took place between Adam and Eve's children. However, this relationship was caused by the necessity of reproduction and was canonized. After the Flood, incest has been forbidden.

One of the greatest events of Eastern civilization of the medieval centuries was creation of Islamic law in the 7th century, which was based on the Holy Quran. It prohibited marriage between family members: mother, daughter, sister, aunt, nephew, niece, step-child, daughter-in-law, a woman who fed a man with her breast in infancy (Kuliev, 2003).

Inquisition - Catholic doctrine of the Emergency Ecclesiastical Court that functioned in Europe, especially in Spain and Portugal in the XIII century, 
did not accept incest; a person guilty of heresy was sentenced to "auto-da-fé" ("Inquisition before the court of History").

Based on the aforementioned, it is obvious that a negative attitude towards "incestuous relations" is mostly common for civilization. However, the social and legal forms of these relations differ. Categories of blood relatives and sexual intercourse have different content in different countries.

used the

Thus, the aim of the given paper is to: formulate the general definition of incest; to initiate new normative approaches of criminal procedures concerning criminalization of voluntary incest among adults and elaborate definitions matching with the legislation of Georgia by using a vast sum off research methods. In particular, private scientific - comparative legal method which makes it possible to discuss the issue in the broader context comparison of the national legislation with the legislative base of the states with main legal systems worldwide; also historical legal analysis which reveals the main tendencies of the development of the legislation in the historical context; General scientific - empiric method (Case Study) studying practices of the European Court of Human Rights; Finally generallogical methods (analysis, synthesis, system approach, generalization), which imply to analyze research papers related to criminal codes and issues in national and international scale.

\section{Leading states and European Court of Human Rights Against Incest}

Worldly recognized criminologists, sociologists, psychologists and anthropologists have been trying to formulate a universal definition of incest, but today it is impossible to distinguish one unified definition out of many interpretations. According to the most common definition, incest is: "Sexual intercourse between people with blood relations to which marriage is prohibited" (Cambridge Dictionary). The legislative practice of states demonstrates that the interpretation of the phenomenon is based on socio-cultural traditions; therefore, regulation policy is quite different. It is noteworthy that voluntary or violent sexual intercourse between a juvenile and an adult is punishable and considered by the criminal law not as "incest", but as other offenses, such as rape - voluntary sexual intercourse between people who have not reached 16/18, lewd act. Voluntary sexual intercourse between adults with blood relations is criminalized only in certain states: Germany; England; Italy; Switzerland; Poland; Sweden; USA; Canada; Chile; Singapore; Hong Kong; Malaysia; Uganda; Zimbabwe and others. Our purpose is to analyze the practices of these states; thus, we will discuss some of them in detail: 
Germany. The Criminal Code of the Federal Republic of Germany regulates the violation of sexual liberty and inviolability of the individual and describes it in chapter 13 - Crimes against Sexual Self-Determination (Straftaten gegen die sexuelle Selbstbestimmung). However, it is interesting to note that Chapter 12 - Offenses related to personal status registration, marriage and family (Straftaten gegen den Personenstand, die Ehe und die Familie) autonomously considers Article 173 - sexual intercourse between blood relatives, according to which incest is punishable.

The subjects of the crime envisaged by Article 173 are those who have reached 18:

- People who have sexual intercourse with blood relatives, namely, with offsprings (Abkömmling);

- People who have sexual relations with blood relatives, namely, with the relative of ascending line (Verwandten aufsteigender);

- Siblings (Geschwister) - in case of both or one common parent.

It should be noted that Criminal Code of Germany does not envisage a relative connection originated by adoption when formulating a crime regarding incest. The objective aspect of the crime is considered sexual intercourse (Beischlaf), which implies any kind of sexual relations that end with or without marriage.

As for punishments envisaged by Article 173:

- Sexual intercourse with the consanguine descendant is punished with imprisonment for not more than three years or a fine;

- Sexual intercourse with a consanguine relative in ascending line is punished with imprisonment for not more than two years or a fine.

According to Article 40, the amount of daily fines is determined by the court; personal characteristics and financial status of the defendant are taken into account. For a daily rate, the amount may be not less than a thousand and not more than thirty thousand Euros.

It is noteworthy that in Germany punishability of incest is a matter of serious consideration. In 2007, the Federal Constitutional Court raised the question of unconstitutionality of the Article 173 of the Criminal Code.

The appellant was the person convicted for incest, P. Stübing. He was born in a poor family. After his parents' divorce, he was adopted by a foreign family. He learned about his younger sister's existence in 2000, after his mother's death. His sister " $\mathrm{S}$ " had a slight mental disorder. Because of this "P" lived with "S". Later the brother-and-sister relationship grew into a married couple's relationship. They had four children; two of them had health problems. When the brother-and-sister relationship was disclosed, $\mathrm{P}$ was charged of the incestuous relations provided by Article 173 of the German Criminal Code. He was sentenced to imprisonment, against which he appealed in all three instances of the court. The Second Chamber of the 
Federal Constitutional Court of Germany did not satisfy the appellant's submission by a majority of votes. According to the defendant's lawyer, Endrik Wilhelm, Article 173 of the German Criminal Code is a reminder of the past and contradicts the principles of a democratic state. The Constitutional Court proved the necessity of criminalization of incest on the basis of social (public order and morality) and the eugenic (biological precondition of individuals towards physical and mental disabilities as a result of incest) factors. Endrik Wilhelm did not accept this because it was unclear for him - if the German Federal State tried to keep moral rules in society, why only sexual intercourse between blood relatives was considered punishable and not marriage or having children. In case P and his sister's children had been born as a result of artificial insemination, $\mathrm{P}$ would not have been punished according to the Article 173, though, breaking of public morality and "unhealthy" child would have been a fact.

The lawyer also said: "The risk of having an "unhealthy" child is when the parents are persons with disabilities or suffer from various severe forms of diseases, though, the state does not forbid sexual intercourse and does not consider it a threat to society that has social or eugenic grounds" (Schmitt, 2015).

In September 2008, P. Stübing applied to the European Court of Human Rights on the grounds that the court verdict violated the right to respect personal and family life guaranteed by Article 8 of the European Convention for the Protection of Human Rights and Fundamental Freedoms one of the important elements of which is sexual liberty. The Court stated that verdict had indeed influenced P. Stübing's personal life as he had been banned from having intimate relationship with his spouse, although, it was not in court's competence to determine the correctness of the state legislation, but to consider the use of the norm for an applicant. In particular, the Court would assess whether there was a public need under Article 8 of the Convention for the conviction of a person and restriction of his rights. "Everyone has the right to be respected for his/her personal and family life, his/her place of residency and correspondence ... interference of the public authority in the exercise of this right is inadmissible unless such interference is in accordance with the law and is necessary for national security, public safety or economic well-being in a democratic society, for the prevention of disorder or crime, for the protection of health or morals or the rights and freedoms of others".

The Court pointed out that the signatory powers of the European Convention have not reached a consensus on the criminalization of the voluntary sexual intercourse between adult blood relatives. The majority supports the punishment of such acts according to the Criminal Code, in the 
rest of the states, marriage of blood relatives is prohibited; so, it can be said, that there is a negative public attitude towards incestuous relations.

In 2007, expert conclusion prepared by Max Planck Institute for Foreign and International Criminal Law also explained that incestuous relations deepen and worsen socio-psychological relationships within the family; such devastating effects have a direct impact on the society.

By the decision of April 12, 2012, the European Court of Human Rights ruled that the case of $\mathrm{P}$. Stübing did not show signs of infringement of rights guaranteed under Article 8 of the Convention. The court fully agreed with the argumentation of the German Federal Constitutional Court in regard to the criminalization of incest, because such ties can destroy the family structure and as a result, the whole society; it can violate the moral principles of a democratic state, and also be the basis for the emergence of genetically anomalous offspring.

USA. Incest is punishable by criminal law in 48 states of the USA, excluding New Jersey and Rhode Island, as well as in the Federal District of Columbia.

As a result of the review of the Criminal Law of the United States, we formulated the explanation of incest: Incest is a voluntary relationship between persons close to the age group of 16 or 18 who are related by blood or affinity. Abusive relationships between adults or abusive or consensual sexual relations between adults and juveniles often have the status of other sexual crimes.

According to the Criminal Code and Norms of the United States, two forms of the close relations can be distinguished:

1. Lineal consanguinity - consists of five branches of kinship: parent, child, grandchild, siblings, aunt, uncle, aunt on father's side, cousin on mother's side, cousin on father's side; half blood relations among them (Cambridge Dictionary).

2. Affinity - Relationship between the person and his/her spouse's blood relatives; such a relation may also arise as a result of adoption of a child (The Free Dictionary By Farlex).

In 21 states (Alaska, Arizona, California, Florida, Idaho, Indiana, Iowa, Kansas, Kentucky, Louisiana, Maine, Massachusetts, Mississippi, Nevada, New Mexico, New York, North Dakota, Oklahoma, Oregon, Washington, Wisconsin) incest is punishable by the Criminal Code when persons who have sexual relations are blood relatives, i.e. there is consanguinity between them. In other states incest is punishable if it is committed by persons who are blood relatives and also by persons who have different kinds of close connections; i.e. they are Affine. It is noteworthy that all persons participating in the act of incest are subject to the offense. 
Maisch Herbert considered that sexual relations can be interpreted as incest only when it is committed between blood relatives. Exactly this is what ruins sanctity of the family. In contrast, Herctor Cavallin stated that blood relationship is not important, the fact that the subjects in a specific case are family members is the main determiner (Sagarin, 1977). Without a doubt, there are different opinions, but we support Maisch's opinion, in that, sexual relations between persons with blood relationship should be put within the limit of special regulations. There is no doubt that intimate relationship between adult adoptees and adoptive parents cannot be ideal, but all immoral actions cannot be criminalized. Though, actions that are not only immoral but also dangerous to society from biological point of view should be followed by strict response.

The facts of genetic anomalies as a result of incest are proved by studies: $11,7 \%$ of incestuous pregnancy $(25 / 213)$, ended up with autosomal-recessive disorders of a child; 16,0\% (34/213) - congenital malformations; 11,7\% (25/213) - acute mental disorders, 14.6\% (31/213) light intellectual disorders (Alvarez, Quinteiro, \& Ceballos, 2011).

The Criminal Code of the USA introduces objective side of a crime in a variety of ways. The actions of subjects committing incest can be as follows:

1. Registered marriage between blood relatives or persons with other kinds of close relations. This form of incest is punishable by criminal code in 26 states and in the Colombian Federal District. It is noteworthy to mention that a similar type of marriage is prohibited in all states by civil law.

2. Cohabitation/Fornication;

3. Adultery - Sexual relationship between persons when at least one person is married.

4. Sexual intercourse - sexual relation of any form, using a part of body or any other object on any part of the body of the other person, penetrating it or not.

5. Sexual Penetration - sexual relation using a part of the body or any other object on any part of the body of the other person penetrating it.

6. Sodomy - Oral or anal sexual intercourse.

7. It should be noted that the majority of the norms provide simultaneous punishment for some of the abovementioned acts. The US Criminal Code provides the following punishment for different forms of incest:

1. Life imprisonment - which is regulated in the legislation of Montana and Nevada states.

2. Deprivation of liberty - e.g. Alabama Criminal Code, according to which incest is deemed a serious offense and belongs to the 4th category 
(Class C Felony) - imprisonment for not more than 10 years but not less than 1 year and 1 day.

3. Fine - 500000 US dollars is considered as a fine for C Class Felony. In the Criminal Code of the US, incest, as the sexual crime committed in the family, takes important place. Namely, in the legislation of 23 states incest is regulated by the chapters that are entitled as follows: Offenses against the Family (Indiana), Family Offences (Arizona), Offences Involving the Family Relations (Colorado).

Under the criminal law of the Colombian Federal District and Florida State, voluntary incestuous relations among adults is considered by the autonomous chapters, which indicate a particularly strict attitude towards this crime.

Singapore. Chapter 16 of the Criminal Code - Offence against the person - contains Article $376 \mathrm{G}$ which considers abusive or consensual sexual relations between blood-related adults and juveniles and is entitled as incest.

According to Article $376 \mathrm{G}$ of the Criminal Code of Singapore, the subject of offence of incestuous ralations may be a male or female who has reached the age of 16 - grandfather, grandmother, son, daughter, grandchild, half brother, half sister (wheather they are registered as married or not). It should be noted that the Criminal Code of Singapore does not consider incestuous ralations between the persons of the same sex punishable. David M. Schneider explained that there were different approaches to determination of homosexual incestuous relations in different countries; however, based on psychopathological evidences, hetero and homosexual relations should be considered as incest (Schneider, 1976). We believe that one of the forms of incest may be homosexual relations, but we support the criminalization of the forms of sexual intercourse that contain the risk of reproduction, i.e. we support only criminalization of heterosexual relationships.

The objective side of the crime is expressed in the following actions:

1. Abusive or consensual sexual relations committed by Male A:

a) Penetrating the female B's vagina or anus using a part of A's body or another object;

b) Penetrating the female B's vagina, anus, or mouth using his genital organ.

In case Male $A$ was aware of the existence of blood relation with Female B, the sentence is imprisonment for up to 5 years and if B is 14 years old, the sentence is deprivation of liberty for up to 14 years.

2. Female $\mathbf{A}$ agrees that Male B:

a) Penetrates Female A's vagina or anus, using a part of A's body or another object; 
b) Penetrates the Female A's vagina, anus, or mouth using Male B's genital organ.

In case Female $A$ was aware of the existence of blood relation with Male B, the sentence is imprisonment for up to 5 years.

It is very important that the Criminal Code of Singapore focuses on the preliminary awareness of consanguinity of the subject committing incest. We believe that the person's punishability by the similar norms should be provided if he/she knew or had to know about the existence of blood relation.

\section{Approaches of Georgia Against Incestuous Relations}

In contrast to Criminal Code policy of Germany, the US and Singapore, at present, Georgia belongs to the number of countries where voluntary incestuous relation among the adults is not punishable by Criminal Code, though, according to Article 1120 of the Civil Code of Georgia, the marriage of blood related persons is prohibited amongst: relatives in the ascending or descending lines, biological and non-biological brothers and sisters. Only the court has the authority to declare such a marriage void (The Civil Code, 2018, January).

Any form of sexual intercourse with a juvenile, whether they are blood related or not, is punished in accordance with general rules, such as Article 137 of the Criminal Code - rape; Article 141 - lewd actions, etc. (The Criminal Code, 2018, January).

It should be noted that in the past, Georgia was less liberal to the issue of incest. In particular, Georgian customary law treated incest with certain carefulness. Incestuous marriage was the subject of strong reaction and was severely punished (e.g. pelting, cutting off from community) (Kekelia, 1993).

In the Old Georgian Ecclesiastical Law, incest was considered a sexual offense (Nadareishvili, 1996). Georgia maintained the same position in the Soviet period - the Criminal Code of the SSR of 1928 provided a special norm, which regulated sexual offenses in the family:

According to Article 173: "Incest i.e. sexual intercourse between the relatives of ascending or descending or among the offshoots of two generations (brother and sister) leads to imprisonment up to three years" (Criminal Code. 1928 Edited). In the Criminal Code of the Soviet Socialist Republic of Georgia (March 1, 1961), we do not see the practice of criminalization of incest (Supreme Council of the Georgian SSR, 1960, March 30). 


\section{Conclusion}

According to the conducted research, there may be revealed a number of fundamental aspects of incest and a complex definition be formulated:

1. Age category of subjects - relations between adults or adults and juveniles;

2. Relations between subjects (blood related: parent, son, daughter, brother and sister, grandmother and grandfather, uncle, cousin; or other kind: Adoptee, stepfather, son-in-law, father-in-law);

3. Gender of subjects - heterosexual or homosexual relations;

4. The objective side of the action is expressed in preliminarily acknowledged abusive or consensual relations that include sexual intercourse (1. traditional; 2. perverted forms) and punishment of such marriage.

We believe that incest can be interpreted as abusive or consensual relation between blood- related adults and juveniles. Consequently, incest is a broad notion. As for punishment, we support the criminalization of heterosexual, preliminarily acknowledged incestuous relations among adults based on dual factors: social - incestuous relation ruins sanctity of the family, alienates children raised in such families from society and eugenic risk of emergence of genetically anomalous offspring.

As a result of the research it has been ascertained that the criminal policy of Georgia has been liberal to incestuous relations between adults since the 60 s of the 20th century. However, based on the reviews of legislative practice of other states, the European Court of Human Rights, and most importantly, based on the moral traditions of our society, we do not accept this approach unconditionally. We strongly believe that only the prohibition of incestuous marriage according to civil law can be considered as the ineffective means of prevention of such antisocial activities. We reckon, that a legislative norm which will criminalize heterosexual, preliminarily acknowledged incestuous relations between adults (sexual intercourse; marriage; application of modern medical means for artificial fertilization) should be established.

\section{References:}

1. Alvarez, G., Quinteiro, \& C., Ceballos, FC. (2011). Inbreeding and genetic disorder. Retrieved from http://cdn.intechweb.org/pdfs/23704.pdf.

2. Cambridge Dictionary. Retrieved from https://dictionary.cambridge.org/dictionary/english/incest.

3. Cambridge Dictionary. Retrieved from https://dictionary.cambridge.org/dictionary/english/consanguinity.

4. Council of Europe. (1950, November 4). Convention on the Protection of Human Rights and Fundamental Freedoms Rome. 
Retrieved from https://matsne.gov.ge/ka/document/view/1208370. [In Georgian]

5. Dolidze, I. (1960). Old east law. Part II. (p. 42). Stalin Tbilisi State University Publishing House. [In Georgian]

6. European Court of Human Rights. Case of Stübing v. Germany. Retrieved from https://hudoc.echr.coe.int/eng\#\{"tabview":["document"],"itemid":["0 01-110314"]\}.

7. Fourth session of the fifth convocation of the Supreme Council of the Georgian SSR on 30 March 1960 of the Soviet Socialist Republic of Georgia of 1 March 1961. "Soviet Georgia". Tbilisi. [In Georgian]

8. Georgia. Parliament. (1997). The Civil Code (2018, January). Retrieved from https://www.matsne.gov.ge/ka/document/view/31702. [In Georgian]

9. Georgia. Parliament. (1999). The Criminal Code (2018, January). Retrieved from https://www.matsne.gov.ge/ka/document/view/16426. [In Georgian]

10. GSSR Public Commissariat Council and Economic Council Issues of Governance. Criminal Code. 1928 Edited. Changes in 1932 December 31.Teflis. 1933. [In Georgian]

11. Inquisition before the court of History. Dec. 27, Retrieved from http://www.lib.ru/HRISTIAN/ATH/inquisit.txt. [In Russian]

12. Kekelia, M. (1993). Georgian customary law. III. (pp. 21-25). Tbilisi, Science. [In Georgian]

13. Kuliev, E.R. (2003). Translation of meanings. Koran. (p. 95). Publishing House of UMMA. [In Russian]

14. Legal Resources. Criminal Codes of USA. Retrieved from https://www.hg.org/crime.html.

15. Legislationline. Criminal Code of the Federal Republic of Germany (1971, amended 2016) (German version). Retrieved from http://www.legislationline.org/documents/section/criminal-codes.

16. Levy-Strauss, C. (1967). Elementary structures of kinship. (p. 29). (1971). Revised Edition. Translated From The French by James Harle Bell, John Richard von Sturner, Rodny Needham. Beacon Press. Boston. Retrieved fromhttps://archive.org/stream/TheElementaryStructuresOfKinshipLe viStrauss/The\%20Elementary\%20Structures\%20Of\%20Kinship\%20\%20Levi\%20Strauss\#page/n65/mode/2up/search/prohibition.

17. Nadareishvili, G. (1986). Essays from law history. (pp. 113-121). Tbilisi, "Soviet Georgia"'. [In Georgian] 
18. Nadareishvili, G. (1996). History of state and law. Lecture course. Part I. The Old East and the Ancient Greece. (pp. 14-23).Tbilisi, Institute of Business and Law. [In Georgian]

19. Nadareishvili, G. (1996). Old Georgian family law. (pp. 8-9). Tbilisi Publishing House "Samtavisi". [In Georgian]

20. Sagarin, E. (1977). Incest: Problems of definition and frequency. (pp. 127-128). The Journal of Sex Research. Vol. 13, \#2. Retrieved from http://www.jstor.org./stable/3811895

21. Schmitt, C. (2015, August 17). Lawyer: Legalize incest!. Retrieved from http://www.dw.com/en/lawyer-legalize-incest/a-18637834.

22. Schneider, D. M. (1976). The Meaning of incest. (pp. 151-152). The Journal Of the Polynesian Society. Vol. 85. \#2. Retrieved from http://www.jstor.org/stable/20705159.

23. Singapure Statutes Online. Penal_Code_(Singapore). Retrieved from https://sso.agc.gov.sg/Act/PC1871. 04.11.2017.

24. Suetonius, G. Tranquill. (n.d). Institutions of Guy. Book one. Retrieved from https://www.google.ge/url?sa=t\&rct=j\&q=\&esrc=s\&source=web\&cd $=1 \&$ cad $=$ rja \&uact $=8 \&$ ved $=0$ ahUKEwjh5oGLk6DXAhUQ5qQKHRe fCJsQFggmMAA\&url=http\%3A\%2F\%2Fartlibrary2007.narod.ru\%2 Finstitucii_gaia.doc\&usg=AOvVaw1AOoCtZSt-Cn1eb_k7GQNX. [In Russian]

25. Suetonius, G. Tranquill. (n.d). Life of the twelve caesars. Fourth book. Caligular from http://ancientrome.ru/antlitr/t.htm?a=1354643464\#4. [In Russian]

26. The Free Dictionary By Farlex. Retrieved from https://legaldictionary.thefreedictionary.com/affinity. 